\title{
ERROR MANAGEMENT CULTURE SCALE: TRANSLATION AND VALIDITY OF A BRAZILIAN VERSION*
}

\author{
JULIANA B. PORTO 1 \\ (iD) https://orcid.org/0000-0001-9164-2719 \\ KATIA E. PUENTE-PALACIOS ${ }^{1}$ \\ (iD) https://orcid.org/0000-0001-5598-8069 \\ LUCIANA MOURÃO ${ }^{2}$ \\ (iD) https://orcid.org/0000-0002-8230-3763 \\ MARIANA M. SANTOS ${ }^{1}$ \\ (iD https://orcid.org/0000-0002-6508-5151 \\ IVY F. ARAUJO ${ }^{1}$ \\ (D) https://orcid.org/0000-0001-8856-6305
}

To cite this paper: Porto, J. B., Puente-Palacios, K. E., Mourão, L., Santos, M. M., \& Araujo, I. F. (2020). Error Management Culture Scale: Translation and validity of a Brazilian version. Revista de Administração Mackenzie, 21 (2), 1-26. doi:10.1590/1678-6971/eRAMG200014

Submission: Jan. 30, 2019. Acceptance: Aug. 26, 2019.

This article was supported by the National Council for Scientific and Technological Development (CNPq) - processes: 403609/2016-0, 303876/2018-2, 312109/2017-2.

1 Universidade de Brasília (UnB), Brasília, DF, Brazil.

2 Universidade Salgado de Oliveira (Universo), Niterói, RJ, Brazil.

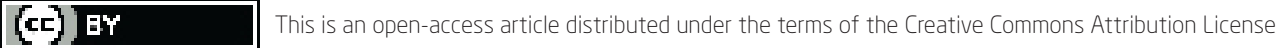

\footnotetext{
This paper may be copied, distributed, displayed, transmitted or adapted if provided, in a clear and explicit way, the name of the journal, the edition, the year and the pages on which the paper was originally published, but not suggesting that RAM endorses paper reuse. This licensing term should be made explicit in cases of reuse or distribution to third parties. It is not allowed the use for commercial purposes.

Este artigo pode ser copiado, distribuído, exibido, transmitido ou adaptado desde que citados, de forma clara e explícita, o nome da revista, a edição, o ano e as páginas nas quais o artigo foi publicado originalmente, mas sem sugerir que a RAM endosse a reutilização do artigo. Esse termo de licenciamento deve ser explicitado para os casos de reutilização ou distribuição para terceiros. Não é permitido o uso para fins comerciais.
} 


\section{ABSTRACT}

Purpose: To provide evidence of the validity of a Brazilian Portuguese version of the Error Management Culture Scale.

Originality/value: Errors are pervasive and cannot be entirely prevented, so it is essential to manage them so as to avoid the worst negative consequences. Error management culture is a set of organizational practices related to communicating about errors, sharing error knowledge, helping in error situations and detecting and handling errors quickly. There was no Brazilian questionnaire for measuring this concept, despite the importance of understanding how we learn from mistakes.

Design/methodology/approach: The Brazilian Error Management Culture Scale was obtained by translation and back-translation procedures. An online and pencil and paper survey were conducted. A sample of 233 employees responded to the 17 items of the scale using five-point scales. Data on demographic and professional variables were also collected.

Findings: Exploratory factor analysis and parallel analysis indicated a one-factor structure, but it can also be represented in terms of four facets of error management. The factor loadings ranged from 0.35 to 0.82 and Cronbach's reliability coefficient was 0.94 , which is consistent with the original study and with other studies using the scale. The results suggested the Brazilian scale will be useful in research and diagnosis. Future studies are needed to confirm these findings in different samples and its predictive validity should be tested to extend the evidence.

\section{KEYWORDS}

Organizational culture. Organizational practices. Error management. Scale validity. Error management culture. 


\section{INTRODUCTION}

On January 25th, 2019, Brazilians were shocked to hear that another tailing dam had collapsed in the state of Minas Gerais, only three years after another dam collapsed, causing Brazil's worst-ever environmental disaster. Hundreds of people were killed or lost their houses and jobs. Brazilians are sad and wondering if lessons were learned from the previous disaster. Why was legislation not changed? Why did the authorities not change the procedures for dealing with this risk? Did the company responsible for the dam communicate about errors? Did they share error knowledge? As Greenpeace Brazil's campaign director, Nilo D'Avila, summed up: “This new disaster with a mining waste tailings dam - this time in Brumadinho - is the sad consequence of a lesson not learned by the Brazilian State and mining companies" (Phillips, 2019). It is human to err, but how can we learn as much as possible from our errors? Is it possible to develop a culture or an organizational context that deals optimally with errors? A group of researchers has established these goals as a priority, arguing that the potential positive consequences of errors, such as innovation, learning, and resilience need to be fully understood (van Dyck, Frese, Baer, \& Sonnentag, 2005).

Two approaches to the problem of human fallibility exist: 1 . the person approach focuses on the errors of individuals, blaming them for forgetfulness, inattention or moral weakness; 2 . the system approach concentrates on the conditions under which individuals work and tries to build defenses to prevent errors or mitigate their effects (Reason, 2000). The error management perspective is that it is useless to try to prevent all errors because errors are pervasive and cannot be entirely prevented.

Error management involves coping with errors to avoid negative error consequences, controlling damage quickly (including reducing the chances of error cascades), and reducing the occurrence of particular errors in the future (secondary error prevention), as well as optimizing the positive consequences of errors, such as long-term learning, performance, and innovations (Frese \& Keith, 2015, p. 665).

Based on the concept of culture as shared norms, values, and practices, van Dyck et al. (2005, p. 1229) proposed the concept of an error management culture and defined it as "organizational practices related to communicating about errors, to sharing error knowledge, to helping in error situations, and to quickly detecting and handling errors". They argued that the visible 
aspects of culture are easier to evaluate accurately and so they focused their scale on shared practice and procedures, instead of values and assumptions.

The Error Management Culture Scale (EMCS) has been used abroad (Cigularov, Chen, \& Rosecrance, 2010; Fischer, Frese, Mertins, \& HardtGawron, 2018; Fruhen \& Keith, 2014; Jung \& Yoon, 2017; Maurer, Hartnell, \& Lippstreu, 2017; van Dyck et al., 2005; Wang, Guchait, Madera, \& Pasamehmetoğlu, 2018). These studies demonstrated that error management culture promotes organizational and individual innovation (Fischer et al., 2018), safety behavior (Cigularov et al., 2010), social-normative motivation to lead, motivation to develop leadership skills (Maurer et al., 2017), job satisfaction (Jung \& Yoon, 2017), manager trust and group efficacy (Wang et al., 2018) and good firm performance (van Dyck et al., 2005), and reduces work-related pain (Cigularov et al., 2010) and accident rates in low and high-risk situations (Fruhen \& Keith, 2014). Mourão (2018), error management culture connected with leadership style and the professional development of subordinates. Error management culture leads to learning. According to Mourão (2018), the organizational context should be aligned with people management policies that favor learning paths, error management, and knowledge management.

There is no Brazilian questionnaire for measuring error management culture, despite the importance of understanding how we learn from our mistakes, hence the aim of this study was to translate the EMCS into Portuguese and provide evidence for the validity of the Brazilian version so that in the future it can be used to improve knowledge in the field.

\section{DEFINITION OF ERROR MANAGEMENT CULTURE}

Organizational culture is a multidisciplinary construct that may be approached from various epistemological perspectives (Smircich, 1983), but Ostroff, Kinicki, and Muhammad (2012) noted that they all have two common factors: the notion of a context divided into multiple layers and socially constructed, being built on shared meanings. Thus, the existence of organizational culture implies that members share values and beliefs that are reflected in rituals, history, and language (Smircich, 1983). In this way, it improves cohesion and promotes organizational survival (Schein, 2004).

With regard to the structure of culture, the notion of division into layers is recurrent in the literature. Schein (2004) described a widely used model in which culture is divided into three layers: the first is explicit, whereas the other two are inner layers and less accessible. In the external layer are 
the artifacts, that is, the visible representations such as language, practices, architecture, and clothes. The second layer encompasses values, which are connected to the ethical principles, norms, and assumptions that guide the organization. Lastly, the innermost layer is the underlying assumptions and premises, which reflect the - often unconsciously held - most profound and unquestioned beliefs of the group.

In terms of the level of analysis, at the macro level, the organizational culture is characterized by shared assumptions that have emerged from the individual perceptions of members (Puente-Palacios, Porto, \& Martins, 2016). Yammarino and Dansereau (2011) emphasized that cultural research is inherently multilevel since it encompasses theories, concepts, models and processes at the individual, group and organizational levels. At the macro level, it becomes possible to relate it to other macro variables, such as effectiveness and turnover (Smircich, 1983).

Most of the scientific research on organizational culture relates to organizational climate. Conceptually, both constructs are related to the notion of a shared social context, grounded in individual meanings, that generates collective patterns and representations (Schneider \& Barbera, 2014). Ashkanasy, Wilderom, and Peterson (2011) distinguished between them, noting that culture is related to deeply rooted assumptions that generate a relatively stable phenomenon, whereas climate is more transitory and is based on shared perceptions about the organizational environment. The premise of both concepts that context is both the product of human interactions and an influence on them, therefore they are not only similar but also complementary concepts (Denison, 1996). Hence, the tendency to focus on narrow aspects of climate, which has been traditional in the field of organizational climate research, is now being imported into research on organizational culture, in an attempt to improve understanding of this complex construct (Schneider, González-Romá, Ostroff, \& West, 2017). This line of research argues that organizational climate should specify practices related to the criteria variable to capture its effect adequately and to improve validity. This has led to research on safety climate and justice climate for example. The notion of error management culture is in line with this approach since it specifies cultural aspects for dealing effectively with errors.

Two issues need to be dealt with before a precise definition of error management culture can be offered. The first is the definition of error, which in the organizational psychology literature is defined as "unintended deviations from plans, goals, or adequate feedback processing, as well as incorrect actions resulting from lack of knowledge" (Frese \& Keith, 2015, 
p. 662). Thus, errors are different from inefficiency, violations of rules, judgment errors, failures and risks (Frese \& Keith, 2015).

Inefficiency involves acting in ways that do not use resources as effectively as possible, yet still allow goals to be achieved, whereas errors hinder the achievement of goals. Violations of rules are intentional, whereas errors are unintentional. Errors of judgment are related to logical and statistical norms, whereas action errors occur in a given context and involve goals and planning. Failure is a broader construct than an error because errors may or may not lead to failure, whereas failure is directly associated with adverse outcomes. Finally, risks are properties of the environment, whereas errors involve an interaction between individuals and the environment (Frese \& Keith, 2015).

The second issue is the principles of the error management perspective. This perspective assumes that it is impossible to prevent all errors and that an error can have positive or negative consequences. Denial of the possibility that errors can occur is counterproductive because it means that staff is not prepared to detect and deal with them (van Dyck, 2009). An error prevention approach reduces the chances of learning from errors and benefiting from them (van Dyck et al., 2005).

Accepting that errors are inevitable enables reliable data on errors to be collected and managed. The error management facilitates systematic efforts to reduce the frequency and severity of adverse events. Typically, errors result from the physiological and psychological limitations of humans, being caused by fatigue, workload, and fear as well as cognitive overload, poor interpersonal communications, imperfect information processing and flawed decision making (Helmreich, 2000).

Empirical data suggest that simply reducing the number of errors does not have an impact on organizational performance, whereas error management actions have a positive relationship with this variable (van Dyck, 2009). Van Dyck (2009) noted that, although the adoption of prevention measures is worthwhile, it cannot solve the problem of errors, since total elimination is impossible. The positive effects of adopting an error management approach rather than a prevention approach were demonstrated in an experiment in which error management improved on-task thoughts and led to better analogical and adaptive transfer performance (Dimitrova, van Dyck, van Hooft, \& Groenewegen, 2015).

Recently Dimitrova, van Hooft, van Dyck, and Groenewegen (2017) conducted an experimental study to investigate the effects of adopting an error prevention strategy, error management strategy, or both, on affective, motivational, cognitive and behavioral outcomes. The results indicated that 
only the error prevention strategy affected outcomes, but separate analysis of each strategy demonstrated that they contributed to variance in different outcomes. Error prevention influenced people's cognitions (fewer on-task thoughts and more negative self-related off-task thoughts) and their actual behavior (performance was worse on an adaptive transfer trial), whereas error management influenced coping. People who received error management instructions were less worried when they were performing the task and reported higher self-efficacy. Thus, this experiment indicates that error prevention may be detrimental to thinking and adaptive transfer performance.

An error management strategy is more effective in avoiding the negative consequences and promoting the positive consequences of errors than error prevention strategy (Frese, 1995; Frese \& Keith, 2015; van Dyck et al., 2005). Error management involves "coping with errors to avoid negative error consequences, controlling for damage quickly, and reducing the occurrence of particular errors in the future, as well as optimizing the positive consequences of errors" (Frese \& Keith, 2015, p. 665). Van Dyck et al. (2005) proposed that these practices should be applied at the organizational level, based on the notion of culture as shared values, norms and practices.

There is a strong error management culture in the aviation sector, possibly because errors in this sector are visible and have severe consequences. There are standardized methods of investigating and documenting errors and disseminating information about lessons learned. Failures of compliance, communication, procedures, proficiency and decision making have been identified as contributing to errors (Helmreich, 2000). The assumption is that error management beliefs, meanings and values are shared, creating a set of formal and informal error management practices and procedures (Fischer et al., 2018). In an error management culture, the focus is on shared perceptions of practices which are assessed more accurately by individuals who perceive these practices (van Dyck et al., 2005).

The model of van Dyck et al. (2005) indicates some practices that are common in error management cultures. Most of these are related to open communication about errors, sharing error knowledge, helping in error situations and detecting and handling errors quickly. This approach promotes the development of error-related knowledge and enhances the effectiveness of error-related actions. It also makes possible other processes, such as learning and innovation, that lead to better firm performance. Thus, the central idea of the model is that cultures with clear error management practices are more effective due to the mediation of learning, innovation, and experimentation. Two studies at the organizational level have lent support to these hypotheses (van Dyck et al., 2005). Thus, error management 
culture is an essential organizational tool for fostering innovation, learning, and resilience (Frese \& Keith, 2015; van Dyck et al., 2005).

\section{THE MEASUREMENT OF ERROR MANAGEMENT CULTURE}

Van Dyck et al. (2005) proposed the EMCS that focused on practices and procedures. Hofstede (2011) pointed out that practices and procedures are an important element of organizational culture since they reflect the way things are done and how workers perceive these actions. Moreover, because they are among the more visible elements of cultural structure, it is easier to assess them accurately (van Dyck et al., 2005).

The scale by van Dyck et al. (2005) was derived from the "error competence" and "learning from errors" dimensions of the Error Orientation Questionnaire (EOQ) (Rybowiak, Garst, Frese, \& Batinic, 1999), which was developed to measure individuals' approach to errors. Van Dyck et al. (2005) adapted the instructions and items to refer to organizational practices. Respondents to van Dyck et al.'s scale are asked to rate the extent to which items apply to people in their organization generally. Changing the object of evaluation in this way is called shifting the referent and is needed whenever a research is interested in information about the group or the organization to which individual respondents belong (Puente-Palacios et al., 2016). In our study, we shifted the referent from the individual to the organization. The response scale ranged from 1 (does not apply at all) to 5 (applies completely).

Van Dyck et al. (2005) tested the validity of their scale in two studies, conducted in the Netherlands and Germany. In study 1, a sample of 350 managers from 65 Dutch organizations answered the 28 -item scale. Factor analysis of the aggregated scores indicated two negatively correlated factors $(r=-0.20)$ : error management culture (alpha $=0.92, n=17)$ and error aversion culture (alpha $=0.88, n=11$ ). Van Dyck et al. also found that the first subscale was positively related to firm goal achievement and economic performance, but not error aversion culture. They concluded that the two factors represented different constructs and that the first factor represented error management culture. The 17 items relating to this factor were analyzed in more detail in study 2. A sample of managers from 47 German companies answered the 17-item EMCS. The scale had an alpha coefficient of 0.93 and error management culture was found to be related positively to return on assets and firm goal achievement. 
Since then, the EMCS has been applied in other studies, relating the error management culture construct to different variables. Cigularov et al. (2010) used a 16-item version of the EMCS to measure error management climate; they reported the full-scale alpha coefficient (0.90) but did not mention any further scale analysis. Fruhen and Keith (2014) used the German version of the scale, adapted to fire-fighting teams. They reported alpha coefficients (from 0.83 to 0.84 ), but no information about validity. Maurer et al. (2017) used an abridged 15-item version of the EMCS, consisting of nine items on error management (alpha $=0.89)$ and six items on error aversion (alpha $=0.90)$. Confirmatory factor analysis (CFA) of all scales used in the study indicated good fit indexes (CFI $=0.95$, RMSEA $=$ 0.07, SRMR =0.06). Fischer et al. (2018) used a 14-item German version of the EMCS and found an alpha coefficient of 0.97 , but did not report validity information.

Wang et al. (2018) conducted exploratory factor analysis (EFA) with data from a sample of 345 employees of hotels in Turkey. They conducted principal component analysis and EFA with varimax rotation of the 16-item EMCS to try to identify the facets proposed by van Dyck et al. (2005). Four of the original factors had eigenvalues greater than one and were retained: error communication $(\alpha=0.87)$, analyzing errors $(\alpha=0.80)$, learning from errors $(\alpha=0.85)$ and error competence $(\alpha=0.78)$. One item was eliminated as its loading on the target factor was less than 0.40 . The four factors explained $70 \%$ of the variance.

Jung and Yoon (2017) used the 17-item EMCS with job satisfaction and turnover intention measures in a sample of 321 hotel employees in Korea. They used CFA to test a measurement model. The three-factor model was a good fit $(\mathrm{CFI}=0.94, \mathrm{RMSEA}=0.08, \mathrm{NFI}=0.91)$. The composite reliability estimate for the EMCS was 0.89, and Cronbach's alpha was 0.97. The variance extracted estimates ranged from 0.64 to 0.80 , indicating acceptable discriminant validity. Although there is evidence for the validity of the EMCS, it has not yet been translated into Portuguese. Hence the aim of this study was to provide evidence of the validity of a Brazilian Portuguese version of the EMCS.

\section{METHOD}

\subsection{Sample}

A sample of 233 public employees answered the questionnaire, 183 were working for the federal government and 50 for the Federal District 
government. Participants were mainly males (48.5\%; $38.6 \%$ females; $12.9 \%$ did not inform), the majority (71.2\%) had no supervision function and they had a mean of 7.7 years of experience in the organization $(\mathrm{SD}=7.3)$. Most participants had a college degree $(40 \%)$ or postgraduate qualification $(40 \%)$.

\subsection{Instruments}

Firstly, the English version of the EMCS was translated to Brazilian Portuguese by a bilingual expert in psychometrics. Then, an independent bilingual translator performed back-translation. The original English version was compared to the back-translated version. We obtained the final version for the scale only after an equivalent version for all items in English and Portuguese were obtained (see the Appendix for final items). The final version was tested in a sample of eight people to evaluate its semantic adequacy. Participants evaluated the 17-items on a five-point scale ranging from 1 (do not apply) to 5 (completely apply to my organization). In addition to the EMCS, the questionnaire contained five questions about specific error management practices and two assessing whether the respondent considered the referent organization to have a specific error management culture. If respondents identify an error management culture at their organization, they should describe practices associated with it. Those questions were an overall evaluation of the presence of error management at their organization and they were used as control variables to check the information given at the questionnaire.

\subsection{Procedures}

Data were collected online and using a paper and pencil version of the questionnaire. After the participating organizations had authorized the researchers to contact employees, emails were sent to all employees or they were contacted in the training sections at the organization. The procedure complied with ethical guidelines: employees were informed about the research objectives and participated voluntarily. To test for method bias, we compared the responses of online and paper-and-pencil groups using t test (Figure 4.3.1). We found no significant differences for 15 of the 17 items, indicating no pattern of differences between the forms of data collection. We, therefore, concluded that the method of administration did not affect responses. 


\section{(Figure 4.3.1)}

\section{T-TEST COMPARING ONLINE AND PAPER-AND-PENCIL ADMINISTRATION}

\begin{tabular}{|c|c|c|c|c|c|}
\hline \multirow{2}{*}{ Item } & \multicolumn{2}{|c|}{ Groups* } & \multirow{2}{*}{$\mathrm{t}$} & \multirow{2}{*}{ Mean difference } & \multirow{2}{*}{$p$ value } \\
\hline & Online & Presencial & & & \\
\hline 1 & 2.63 & 2.59 & 0.23 & 0.04 & 0.82 \\
\hline 2 & 2.66 & 2.92 & -1.29 & -0.25 & 0.20 \\
\hline 3 & 3.10 & 3.08 & 0.12 & 0.02 & 0.91 \\
\hline 4 & 3.06 & 3.20 & -0.82 & -0.15 & 0.42 \\
\hline 5 & 2.53 & 2.63 & -0.50 & -0.1 & 0.62 \\
\hline 6 & 2.51 & 2.49 & 0.09 & 0.02 & 0.93 \\
\hline 7 & 2.98 & 2.73 & 1.31 & 0.25 & 0.20 \\
\hline 8 & 3.16 & 3.02 & 0.68 & 0.14 & 0.50 \\
\hline 9 & 2.71 & 2.82 & -0.60 & -0.11 & 0.58 \\
\hline 10 & 2.91 & 2.92 & -0.01 & -0.01 & 0.99 \\
\hline 11 & 3.26 & 3.14 & 0.65 & 0.12 & 0.52 \\
\hline 12 & 2.78 & 2.82 & -0.19 & -0.04 & 0.85 \\
\hline 13 & 3.02 & 2.88 & 0.87 & 0.15 & 0.39 \\
\hline 14 & 3.05 & 2.90 & 0.82 & 0.15 & 0.42 \\
\hline 15 & 2.13 & 1.80 & 2.25 & 0.33 & 0.03 \\
\hline 16 & 3.62 & 2.86 & 3.64 & 0.77 & 0.01 \\
\hline 17 & 2.97 & 2.93 & 0.21 & 0.04 & 0.83 \\
\hline
\end{tabular}

* Paper and pencil $N=50$; online $N=183$.

Source: Elaborated by the authors.

\section{RESULTS}

The aim of our analysis was to determine the psychometric properties of the Brazilian EMCS and provide empirical evidence of its validity. We, therefore, carried out EFA. We chose an EFA to verify if the culture has a preponderant role in the organization of the components and dimensions of the measure. Van Dyck et al. (2005), for example, showed that certain 
error management practices are more common in certain cultures. We decided to identify the structure of the EMCS in a given culture using EFA instead of asserting that the phenomenon does not vary across cultures and using a CFA.

The analysis was organized in three steps: 1 . viability of factor analysis, 2. factor extraction, and 3. reliability analysis. We started by describing the normality of the data distribution. The factorial structure reflects the sample characteristics and, thus, each time we use a scale the evidence of validity should be checked and the information of the sample distribution provided (Lloret, Ferreres, Hernández, \& Tomás, 2017). It is essential to note, however, that according to Hair, Anderson, Tatham, and Black (2005, p. 98), the assumptions for factor analysis "are more conceptual than statistics" and lack of normality, homoscedasticity and linearity will only reduce the observed correlations. The analyses presented are intended to describe the distribution of data in our sample and does not imply that adjustments are needed. Absolute skewness values ranged between 0.03 and 0.72 (in absolute terms), which is compatible with a normal distribution using the Miles and Shevlin (2001) criterion, that asymmetry values below 1 show that data distribution is very close to normal. Absolute kurtosis values ranged between 0.15 and 1.05 (absolute values). Miles and Shevlin (2001) noted that 0 represents a perfectly normal distribution, so our data showed a slight deviation from normality.

The value of the KMO sample adequacy statistic (0.93), the determinant $(1.24$ E-005) and Bartlett's test of sphericity $(p<0.001)$ all indicated that the data were suitable for factor analysis. Moreover, an inspection of the correlation matrix revealed that significant associations ranged between 0.7 and 0.17 . Nonsignificant correlation between the 17 items occurred in $2 \%$ of the cases.

Before proceeding to the second step - factor extraction -, some guiding criteria were defined. We used the Kaiser-Guttman criteria, the scree plot and the parallel analysis. The Kaiser-Guttman test indicated that four factors could be identified in the data, but it is important to remember that this test indicates the maximum number of factors that could be extracted, not the most appropriate number. The scree plot and the parallel analysis suggested the presence of only one factor. Moreover, the factor structure found in the original study was considered, because, although this study was conducted in different countries, its theoretical basis was similar (study 2 from van Dyck et al., 2005). Together, these results indicated that a one-factor solution should be adopted. 
The one-factor model captured about $51 \%$ (50.58\%) of the variance in error management culture scores. The factorial loads of the items were satisfactory, above 0.30, according to Tabachnick and Fidell (2007). The observed factor loadings were between 0.35 and 0.82 (Figure 5.1), and the most representative item was number 9 (after an error occurs, people in this organization think a lot about how to correct it).

\section{(Figure 5.1)}

FACTOR STRUCTURE FOR THE ERROR MANAGEMENT CULTURE SCALE

\begin{tabular}{cc}
\hline Items & Factor loadings \\
\hline 9 & 0.82 \\
\hline 5 & 0.79 \\
\hline 14 & 0.77 \\
\hline 4 & 0.76 \\
\hline 17 & 0.76 \\
\hline 6 & 0.76 \\
\hline 2 & 0.72 \\
\hline 10 & 0.69 \\
\hline 8 & 0.69 \\
\hline 15 & 0.67 \\
\hline 7 & 0.67 \\
\hline 3 & 0.66 \\
\hline 11 & 0.64 \\
\hline 13 & 0.63 \\
\hline 12 & 0.60 \\
\hline 1 & 0.59 \\
\hline 16 & 0.35 \\
\hline Pronbach's alpha & 17 \\
\hline Item-total mean correlation & $50.58 \%$ \\
\hline & 0.94 \\
\hline & 0.66 \\
\hline
\end{tabular}

Source: Elaborated by the authors. 
Having defined a suitable number of factors, the third step was to investigate the reliability of the single factor identified. We calculated Cronbach's alpha and the average value of the item-total correlations. The results revealed the adequacy of the solution $(\alpha=0.94$; average item-total correlation $=0.66$ ).

A careful analysis of the behavior of the individual items indicated that the deletion of any one of them would not significantly improve the alpha value of the scale. Although the item-total correlation for item $16(r=0.29$; in our organization, we seek to achieve our final goal, even if we make mistakes; factor loading $=0.36$ ) was relatively low, we decided to retain this item, as our study provides the first test of the scale in Brazil. In addition, the item refers to an important feature of the construct, that is, errors should not be avoided, and they happen when we try to do things.

The reliability analysis for the one-factor solution demonstrated its pertinence but suggested potential problems with item 16. Based on the factor loading, there was no reason to drop this item, since the loading was higher than the minimum specified by Tabachnick and Fidell (2007), and excluding it did not improve factor reliability. However, the lack of convergence between this item and the others suggests some disparity in content. Since the factor solution is contingent on the data collected, we chose to retain this item, but its performance should be closely monitored in future studies. Replications should indicate whether this item needs to be rephrased or excluded altogether.

As well as reducing the 17 items to the mean of a single factor, we investigated the presence of facets matching the theoretical dimensions of error management culture described by van Dyck et al. (2005). The analysis revealed the pertinence of retaining only one factor. However, content analysis of the items suggested theoretically congruent subsets. These subsets were called facets. We identified four dimensions of error management culture: error communication, analysis of errors, learning from errors and error competence. The decision to identify subsets of items relating to these dimensions of error management culture was supported by the work of Wang et al. (2018), who identified four factors representing different types of error management behavior. Thus, we proceeded to extract four facets, forcibly organizing the 17 items into four sets. This decision was also substantiated by the results of the Guttman-Kaiser test, which had indicated that four factors could be identified in the data matrix.

We extracted facets using the Principal Axis Factoring (PAF) method with oblique rotation (Promax) and pairwise deletion of missing cases. The results of this extraction were adequate since the sets of items were highly consistent with the theoretical predictions. Facet 1 aggregated six items related to teams' 
cognitive effort to analyze errors (items 2, 5, 6, 9, 12, 15). They typically referred to thinking, analyzing and reflecting, demonstrating similarity with the "analyzing" factor identified by Wang et al. (2018). The factor loadings varied between 0.90 and 0.60 , the internal reliability (Cronbach's alpha) of facet 1 was 0.90 and the mean item-total correlation was 0.73 .

Facet 2 consisted of four items describing team behaviors related to the exchange of information about an error (items $1,3,8,10$ ). This facet is similar to Wang et al.'s (2018) “communication" factor. The factor loadings varied between 0.90 and 0.47 , Cronbach's alpha and the mean item-total correlation were satisfactory $(\alpha=0.84 ; r=0.68)$.

Facet 3 consisted of four items related to learning from errors (items 4 , $11,14,17)$. These behaviors are compatible with the "learning" factor identified by Wang et al. (2018). The factor loadings varied between 0.47 and 0.79 , Cronbach's alpha and the mean item-total correlation were also satisfactory $(\alpha=0.88 ; r=0.75)$.

Finally, facet 4 consisted of three items dealing with correcting errors, reaching goals or handling errors (items $7,13,16$ ) and it could be likened to the "competence" factor of Wang et al. (2018). The factor loadings varied between 0.50 and 0.54 , Cronbach's alpha was 0.70 , and the mean total item correlation was 0.49 .

The fact that we were able to extract four facets related to theoretically distinct aspects of error management suggests the presence of primary and secondary factors in the scale. Thus, we conducted an analysis to identify the hierarchical organization of the structure in first and second-order factors (Figure 5.2). The results revealed that three of the four facets (analyzing, learning and communication) were strongly linked to a secondary factor, however, the competence facet had a lower factorial load, suggesting that it is less important to the structuring of error management.

(Figure 5.2)

SECOND-ORDER FACTORIAL SOLUTION FOR THE ERROR MANAGEMENT CULTURE SCALE

\begin{tabular}{lc}
\multicolumn{1}{c}{ Facets } & Factor loading \\
\hline Facet 1 - Analyzing & 0.85 \\
\hline Facet 3- Learning & 0.85 \\
\hline Facet 2-Communication & 0.78 \\
\hline Facet 4 - Competence & 0.69 \\
\hline
\end{tabular}

Total variance explained - 63.15\%.

Source: Elaborated by the authors. 
Overall, these results indicate that the Brazilian EMCS has adequate psychometric characteristics and provide support for the theoretical model. The implications of our results for the theory and practice of error management in organizations are discussed below.

\section{DISCUSSION}

The results of our analysis suggest that the Brazilian version of the EMCS has a one-factor structure, but can also be represented in terms of four facets. The structure we uncovered is in line with the findings of the original study of the EMCS by van Dyck et al. (2005) and with other studies using the scale (Cigularov et al., 2010; Fruhen \& Keith, 2014; Jung \& Yoon, 2017; Maurer et al., 2017). The Cronbach's alpha indicated that the Brazilian version has good internal consistency. Before the application of the Brazilian version can be recommended, however, it is important that more research is done to confirm its structure and psychometric properties, paying particular attention to the behavior of item 16 .

Regarding the facet extraction, we should emphasize the high degree of similarity between the content of the four facets we extracted and van Dyck et al.'s (2005) theoretical dimensions of error management: open communication about errors, sharing error knowledge, helping in error situations and detecting and handling errors quickly. Additionally, as mentioned before, we also found a high similarity between these facets and the factors identified by Wang et al. (2018).

As well as having sound theoretical foundations and being closely aligned with the results of a previous study, our extraction of four facets has practical advantages. The Brazilian EMCS could be used for organizational analysis, as it provides detailed information about the different behaviors associated with each facet. Analysis of the facets provides specific information, for example about a team's ability to learn from errors, to reflect on them, to share information about an error or to deal with errors when they occur. Thus it can be used to identify specific gaps in error management and hence to support the design of interventions to tackle such gaps.

As well as analyzing the factorial structure of the scale, it would be interesting, for comparative purposes, to apply the scale in organizations that have transparent error management practices. The mean score on the EMCS 2.87 ( $S D=0.78)$ suggests that the organizations involved in this study did not have a strong error management policy. The global evaluation 
questions included in the questionnaire indicated that $36 \%$ of the participants perceived that their organization had a specific error management culture and $20 \%$ perceived some kind of error management culture. Although it may seem that the mean for the EMCS should be smaller when compared to the answer to these global questions, it is important to highlight that individuals may not fully understand what an error management culture is. They can report accurately whether specific practices occur or not in their organization, but do not associate these practices with a specific error management culture. These results may well reflect the reality of public organizations that are from the service sector. However, it is important to investigate the error management culture in industrial environments and innovation areas. In such environments, there may be a clear policy for dealing with errors and, thus, a set of practices easily identified by individuals. This may improve the scale accuracy for capturing the phenomenon. Such studies would also indicate the scale accuracy to discriminate an error culture between organizations.

The findings provide support for the relevance of the EMCS because the error management culture construct encompasses many organizational practices, ranging from communication patterns to helping behaviors (van Dyck et al., 2005), that can be found in any company. We should highlight that EMCS captures only organizational practices and not values or assumptions. Since practices are amongst the visible aspects of a culture, it is relatively easy to assess them through employee reports and such reports should be fairly accurate. Although the EMCS captures the rate of use of multiple practices, they are all related to a one-dimensional error management construct, hence, the scale has a one-factor structure. Four facets of error management can also be identified using the scale. In other words, the EMCS captures the general error management culture of an organization as well as the specific practices that constitute that culture.

In concrete terms, the advantage of a scale to diagnose an error management culture relies on the importance of this type of culture for organizations. Frese and Keith (2015), and van Dyck et al. (2005) argued that organizations in which specific error management practices are pervasive are more likely to display competitive advantages, such as learning, resilience, and innovation. In addition, the development of an error management culture can help to increase the motivation and the capacity of the leadership, as well as contributing to the professional development and career success of employees (Maurer et al., 2017; Mourão, 2018).

The ability to measure error management culture accurately is a prerequisite for interventions that aim to foster a healthy error management culture. 
If the organization invests in an error management culture, it can take advantage of its positive consequences. The EMCS can help practitioners to assess the error management culture of organizations. The tool's focus on concrete practices increases its practical utility because such concrete practices are more amenable to management and intervention.

The psychometric properties of the EMCS and its alignment with the theoretical characteristics of the error management culture construct provide support for the adequacy of the measure in a Brazilian sample. It is important, however, to point out the limitations of our research. First, we used a convenience sample composed of public employees, most of whom had a college degree. Thus, the profile of our sample differs from that of the average Brazilian worker, the majority of whom have only an elementary school certificate $-51 \%$ of people aged over 25 years old (Instituto Brasileiro de Geografia e Estatística, 2018). On the other hand, our sample appears to have been representative of Brazilian public employees, the majority of whom (75\%) have a college degree (Escola Nacional de Administração Pública, 2018).

Second, due to the difficulty of collecting data from multiple organizations, the data were only analyzed at the individual level. Future research should expand the sample to permit an organizational level analysis. Finally, our data do not address the issue of external validity; we could not correlate the measurement errors (or facets) with other variables, due to the low variance in our sample. Nevertheless, the Brazilian EMCS's close alignment with the theoretical properties of the error management culture construct is an argument for its adequacy.

Thus, we conclude that the objective providing evidence of the validity of a Brazilian Portuguese version of the EMCS was successfully achieved. The results suggest that the Brazilian EMCS is suitable and results are encouraging, but future studies are needed to confirm the findings in different populations and extend the evidence of validity. Moreover, analysis of the relationship between error management culture and other variables, such as organizational effectiveness and innovation, should also be carried out to provide evidence of the predictive validity and utility of the EMCS in the Brazilian context. 


\section{ESCALA DE CULTURA DE GERENCIAMENTO DE ERROS: TRADUÇÃO E EVIDÊNCIAS DE VALIDADE PARA AMOSTRAS BRASILEIRAS}

\section{RESUMO}

Objetivo: O objetivo deste artigo foi identificar evidências de validade para a versão em português do Brasil da Escala de Cultura de Gerenciamento de Erros.

Originalidade/valor: O erro é generalizado e não pode ser totalmente evitado. Assim, é essencial promover o gerenciamento para lidar com erros e evitar consequências negativas. A cultura de gerenciamento de erros compreende um conjunto de práticas organizacionais relacionadas à comunicação sobre erros, ao compartilhamento de conhecimento sobre os erros, à ajuda em situações de erro e à rápida detecção e tratamento de erros. No Brasil, não foi encontrado questionário para medir esse conceito, apesar da relevância de entender como aprendemos com nossas falhas.

Design/metodologia/abordagem: A Escala de Cultura de Gerenciamento de Erros foi obtida após os procedimentos de tradução para português e tradução reversa. Realizaram-se pesquisas on-line e presencial. Uma amostra de 233 trabalhadores respondeu à escala de 17 itens, avaliados por uma escala de cinco pontos. Variáveis demográficas e profissionais também foram coletadas.

Resultados: Os resultados de uma análise fatorial exploratória e da análise paralela suportaram uma estrutura unifatorial, mas também a representação de quatro facetas do gerenciamento de erros. As cargas fatoriais variaram de 0,35 a 0,82, e o coeficiente de confiabilidade de Cronbach foi de 0,94 . A estrutura encontrada está alinhada com o estudo original e com outros estudos usando a escala. Os resultados apontaram que se trata de um instrumento promissor para pesquisas e diagnósticos. Estudos futuros são necessários para confirmar esses achados com diferentes públicos e testar sua validade preditiva para ampliar as evidências.

\section{PALAVRAS-CHAVES}

Cultura organizacional. Práticas organizacionais. Gerenciamento de erros. Validade de escala. Cultura de gerenciamento de erros. 


\section{REFERENCES}

Ashkanasy, N., Wilderom, C. P. M., \& Peterson, M. F. (2011). Introduction to the handbook of organizational culture and climate. In N. Ashkanasy, C. P. M. Wilderom, \& M. F. Peterson (Eds.). The handbook of organizational culture and climate (2nd ed., pp. 50-76). Thousand Oaks: Sage.

Cigularov, K. P., Chen, P. Y., \& Rosecrance, J. (2010). The effects of error management climate and safety communication on safety: A multi-level study. Accident Analysis and Prevention, 42(5), 1498-1506. doi:10.1016/j. aap.2010.01.003

Denison, D. R. (1996). What is the difference between organizational culture and organizational climate? A native's point of view on a decade of paradigm wars. Academy of Management Review, 21 (3), 619-654. doi:10.54 65/AMR.1996.9702100310

Dimitrova, N. G., van Dyck, C., van Hooft, E. A. J., \& Groenewegen, P. (2015). Don't fuss, focus: The Mediating effect of on-task thoughts on the relationship between error approach instructions and task performance. Applied Psychology, 64(3), 599-624. https://doi.org/10.1111/apps.12029

Dimitrova, N. G., van Hooft, E. A. J., van Dyck, C., \& Groenewegen, P. (2017). Behind the wheel: What drives the effects of error handling? Journal of Social Psychology, 157(6), 658-672. doi:10.1080/00224545.2016. 1270891

Escola Nacional de Administração Pública (2018). Informe de pessoal. Retrieved from http://repositorio.enap.gov.br/handle/1/3215

Fischer, S., Frese, M., Mertins, J. C., \& Hardt-Gawron, J. V. (2018). The role of error management culture for firm and individual innovativeness. Applied Psychology, 67(3), 428-453. doi:10.1111/apps.12129

Frese, M. (1995). Error management in training: Conceptual and empirical results. In C. Zucchermaglio, S. Bagnara, \& S. U. Stucky (Eds.). Organizational learning and technological change (pp. 112-124). Palo Alto, CA: Springer.

Frese, M., \& Keith, N. (2015). Action errors, error management, and learning in organizations. Annual Review of Psychology, 66(1), 661-687. doi:10.1146/ annurev-psych-010814-015205

Fruhen, L. S., \& Keith, N. (2014). Team cohesion and error culture in risky work environments. Safety Science, 65, 20-27. doi:10.1016/j.ssci.2013. 12.011 
Hair, J. F., Anderson, R. E., Tatham, R. L., \& Black, W. C. (2005). Análise multivariada de dados (5a ed.). Porto Alegre: Bookman.

Helmreich, R. L. (2000). On error management: Lessons from aviation. British Medical Journal, 320(7237), 781-785. doi:10.1136/bmj.320.7237.781

Hofstede, G. (2011). Dimensionalizing cultures: The Hofstede model in context. Online Readings in Psychology and Culture, 2(1), 1-26. doi:10.9707/ 2307-0919.1014

Instituto Brasileiro de Geografia e Estatística (2018). Pesquisa Nacional por Amostra de Domicílios Contínua - PNAD Contínua. Retrieved from https://agenciadenoticias.ibge.gov.br/media/com_mediaibge/arquivos/0 5dc6273be644304b520efd585434917.pdf

Jung, H. S., \& Yoon, H. H. (2017). Error management culture and turnover intent among food and beverage employees in deluxe hotels: The mediating effect of job satisfaction. Service Business, 11, 785-802. doi:10.1007/s11628016-0330-5

Lloret, S., Ferreres, A., Hernández, A., \& Tomás, I. (2017). El análisis factorial exploratorio de los ítems: Análisis guiado según los datos empíricos y el software. Anales de Psicología, 33(2), 417-432. doi:10.6018/analesps. 33.2.270211

Maurer, T. J., Hartnell, C. A., \& Lippstreu, M. (2017). A model of leadership motivations, error management culture, leadership capacity, and career success. Journal of Occupational and Organizational Psychology, 90 (4), 481-507. doi:10.1111/joop.12181

Miles, J., \& Shevlin, M. (2001). Applying regression \& correlation: A guide for students and researchers. London: Sage.

Mourão, L. (2018). The role of leadership in the professional development of subordinates. In S. Göker (Ed.). Leadership. London: IntechOpen. doi:10.5772/intechopen.76056

Ostroff, C., Kinicki, A. J., \& Muhammad, R. S. (2012). Organizational culture and climate. In I. B. Weiner, N. W. Schmitt, \& S. Highhouse (Eds.). Handbook of psychology (2nd ed.). Hoboken, NJ: John Wiley \& Sons. doi:10. 1002/9781118133880.hop212024

Phillips, D. (2019, January 26). Brazil dam collapse: 10 bodies found and hundreds missing. The Guardian. Retrieved from https://www.theguardian. com/world/2019/jan/25/brazil-dam-collapse-news-latest-mining-disasterbrumadinho 
Puente-Palacios, K. E., Porto, J. B., \& Martins, M. C. F. (2016). A emersão na articulação de níveis em Psicologia Organizacional e do Trabalho. Revista Psicologia, Organizações e Trabalho, 16 (4), 358-366. doi:10.17652/rpot/2016. 4.12603

Reason, J. (2000). Human error: Models and management. British Medical Journal, 320(7237), 768-770. doi:10.1136/bmj.320.7237.768

Rybowiak, V., Garst, H., Frese, M., \& Batinic, B. (1999). Error Orientation Questionnaire (EOQ): Reliability, validity, and different language equivalence. Journal of Organizational Behavior, 20, 527-547.

Schein, E. H. (2004). Organizational culture and leadership (3rd ed.). San Francisco: Jossey-Bass.

Schneider, B., \& Barbera, K. M. (2014). The Oxford handbook of organizational climate and culture. New York: Oxford University Press.

Schneider, B., González-Romá, V., Ostroff, C., \& West, M. A. (2017). Organizational climate and culture: Reflections on the history of the constructs in the Journal of Applied Psychology. Journal of Applied Psychology, 102(3), 468-482. doi:10.1037/ap10000090

Smircich, L. (1983). Concepts of culture and organizational analysis. Administrative Science Quarterly, 28(3), 339-358. doi:10.2307/2392246

Tabachnick, B. G., \& Fidell, L. S. (2007). Using multivariate statistics (5th ed.). Boston, NY: Allyn \& Bacon.

van Dyck, C. (2009). The tragic 1996 Everest expedition: A tale of error culture. Netherlands Journal of Psychology, 65(1), 22-34. doi:10.1007/BF 03080124

van Dyck, C., Frese, M., Baer, M., \& Sonnentag, S. (2005). Organizational error management culture and its impact on performance: A two-study replication. Journal of Applied Psychology, 90(6), 1228-1240. doi:10.10 37/0021-9010.90.6.1228

Wang, X., Guchait, P., Madera, J. M., \& Pasamehmetoğlu, A. (2018). Is “Do it right the first time" necessarily right? International Journal of Contemporary Hospitality Management, 30(3), 1398-1418. doi:10.1108/IJCHM-01-20170038

Yammarino, F. J., \& Dansereau, F. (2011). Multilevel issues in organizational culture and climate research. In N. M. Ashkanasy, C. P. M. Wilderom, \& M. F. Peterson (Eds.). The handbook of organizational culture and climate (2nd ed., pp. 50-76). Thousand Oaks: Sage. 


\section{(APPEndiX)}

\section{ESCALA DE CULTURA DE GERENCIAMENTO DE ERROS}

Este questionário diz respeito a situações de trabalho. Nós gostaríamos de saber sua opinião sobre como as pessoas da sua organização, em geral, lidam com situações difíceis e com erros ou enganos. Por favor, leia as afirmações abaixo e assinale uma das cinco opções de resposta.

Lembre-se de que você deve responder de acordo com o que ocorre na sua organização.

\begin{tabular}{ccccc}
\hline $\begin{array}{c}\text { Não se } \\
\text { aplica }\end{array}$ & $\begin{array}{c}\text { Aplica-se } \\
\text { um pouco }\end{array}$ & $\begin{array}{c}\text { Aplica-se } \\
\text { moderadamente }\end{array}$ & $\begin{array}{c}\text { Aplica-se } \\
\text { bastante }\end{array}$ & $\begin{array}{c}\text { Aplica-se } \\
\text { completamente }\end{array}$ \\
\hline
\end{tabular}

1. Em nossa empresa, quando as pessoas cometem erros ou enganos, elas compartilham as informaç̃̃es com os outros para que eles não cometam o mesmo erro.

2. Se um erro ou engano acontece em nossa organização, nós refletimos sobre ele para entender como ele aconteceu.

3. Se não conseguimos lidar com um erro ou engano, nós contamos com os outros colegas.

4. Em nossa organização, erros nos auxiliam a aprimorar o trabalho.

\section{Nesta organização, nós pensamos muito sobre como um erro poderia ter sido evitado. \\ 6. Se algo dá errado, nós dedicamos um tempo para analisar o ocorrido. \\ 7. Se um erro acontece em nossa organização, sempre há alguém que sabe como lidar com o problema.}
8. Em nossa organização, quando as pessoas não são capazes de lidar com um erro, elas podem contar com os colegas.

\section{Depois que um erro ocorreu, as pessoas nesta organização pensam bastante sobre como corrigi-lo.}
10. Em nossa organização, quando as pessoas cometem um erro, elas pedem conselhos aos colegas.




\begin{tabular}{|c|c|c|c|c|c|}
\hline & \\
\hline & $\begin{array}{l}\text { Não se } \\
\text { aplica }\end{array}$ & $\begin{array}{l}\text { Aplica-se } \\
\text { um pouco }\end{array}$ & $\begin{array}{l}\text { Aplica-se } \\
\text { moderadamente }\end{array}$ & $\begin{array}{l}\text { Aplica-se } \\
\text { bastante }\end{array}$ & $\begin{array}{l}\text { Aplica-se } \\
\text { completamente }\end{array}$ \\
\hline $\begin{array}{l}\text { 11. Erros nos fornecem informações importantes } \\
\text { sobre como dar prosseguimento ao nosso } \\
\text { trabalho. }\end{array}$ & [ ] & [ ] & [ ] & [ ] & [ ] \\
\hline $\begin{array}{l}\text { 12. Em nossa organização, quando alguém faz } \\
\text { alguma coisa errada, nós imediatamente a } \\
\text { corrigimos. }\end{array}$ & [ ] & [ ] & [ ] & [ ] & {$[\quad]$} \\
\hline $\begin{array}{l}\text { 13. Se for possível corrigir um engano de alguma } \\
\text { forma, nós costumamos saber como fazê-lo. }\end{array}$ & [ ] & [ ] & [ ] & [ ] & [ ] \\
\hline $\begin{array}{l}\text { 14. Em nossa organização, erros nos ajudam a } \\
\text { aprimorar nosso trabalho. }\end{array}$ & [ ] & [ ] & [ ] & [ ] & [ ] \\
\hline $\begin{array}{l}\text { 15. Em nossa organização, quando um erro ou } \\
\text { engano acontece com alguém, as pessoas } \\
\text { tentam analisá-lo exaustivamente. }\end{array}$ & [ ] & [ ] & [ ] & [ ] & [ ] \\
\hline $\begin{array}{l}\text { 16. Em nossa organização, buscamos alcançar } \\
\text { nosso objetivo final, mesmo que nós } \\
\text { cometamos erros ou enganos. }\end{array}$ & [ ] & [ ] & [ ] & [ ] & [ ] \\
\hline $\begin{array}{l}\text { 17. Em nossa organização, nós temos aprendido } \\
\text { muito com erros e enganos. }\end{array}$ & {[]} & [ ] & [ ] & [ ] & [ ] \\
\hline
\end{tabular}

Finalmente, há algumas questões concretas sobre a sua organização. Mais uma vez, se a sua organização é composta por mais de um setor, por favor, responda às questões somente em relação ao setor em que você trabalha.

Os erros e suas soluções são discutidos durante as reuniões?

$\begin{array}{lcc}{[\quad]} & {[\quad]} & {[} \\ \text { Sim } & \text { Às vezes } & \text { Não }\end{array}$

Os erros são registrados em diários, com o intuito de discutir os erros e de aprender com

[ ]

Sim

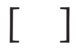

Não eles?

Existe um procedimento padrão que permita a reflexão sobre os possíveis erros decorrentes de tomadas de decisão importantes?

[ ]

Sim

[ ]

Não

Existem reuniões especiais que tenham o objetivo de melhorar a qualidade do trabalho?
[ ]

Sim
[ ]

Não 
Existem reuniões especiais nas quais erros são discutidos, com o objetivo de melhorar a qualidade do trabalho e de aprender a partir

[ ]

Sim
[ ]

Não dos erros?

Existe uma cultura organizacional?

$\begin{array}{lcc}{[]} & {[]} & {[]} \\ \text { Sim } & \begin{array}{c}\text { Em certa } \\ \text { medida }\end{array} & \text { Não }\end{array}$

Em caso afirmativo, como essa cultura se mostra?

Quais são as características dessa cultura?

Você consegue nomear alguns dos slogans/lemas/frases que melhor expressam essa cultura?

Existe uma cultura organizacional clara quanto aos erros, enganos e problemas?

$\begin{array}{lcc}{[\mathrm{]}} & {[\mathrm{]}} & {[\mathrm{]}} \\ \mathrm{Sim} & \begin{array}{c}\text { Em certa } \\ \text { medida }\end{array} & \text { Não }\end{array}$

Em caso afirmativo, como essa cultura se mostra?

Quais são as características dessa cultura?

Você consegue nomear alguns dos slogans que melhor expressam essa cultura? 


\section{AUTHOR NOTES}

Juliana B. Porto, PhD by the Institute of Psychology, University of Brasilia (UnB); Katia E. Puente-Palacios, PhD by the Institute of Psychology, University of Brasilia (UnB); Luciana Mourão, PhD by the Institute of Psychology, University of Brasilia (UnB); Mariana M. Santos, graduated by the Institute of Psychology, University of Brasilia (UnB); \& Ivy F. de Araujo, graduated by the Institute of Psychology, University of Brasilia (UnB).

Juliana B. Porto is now associate professor at the Institute of Psychology of University of Brasilia $(\mathrm{UnB})$; Katia E. Puente-Palacios is now associate professor at the Institute of Psychology of University of Brasilia (UnB); Luciana Mourão is now titular professor at the Psychology Graduate Program of Salgado de Oliveira University (Universo); Mariana M. Santos is now master student at the Graduate Program in Social, Work and Organizational Psychology of University of Brasilia (UnB); Ivy F. de Araujo is now egress at the Institute of Psychology of University of Brasilia (UnB). Correspondence concerning this article should be addressed to Juliana B. Porto, Universidade de Brasília, campus Darcy Ribeiro, ICC Sul, Sala AT-048, Asa Norte, Brasília, Distrito Federal, Brazil, CEP 70.910-900.

E-mail: jbporto@unb.br

\section{EDITORIAL BOARD}

Editors-in-chief

Janette Brunstein

Silvia Marcia Russi de Domênico

Associated Editor

Renata Silva de Carvalho Chinelato

Technical Support

Vitória Batista Santos Silva

\section{EDITORIAL PRODUCTION}

Publishing Coordination

Jéssica Dametta

Editorial Intern

Paula Di Sessa Vavlis

Language Editor

Daniel de Almeida Leão
Layout Designer
Emap

Graphic Designer

Libro 